\author{
Krzysztof Niewęgłowski \\ Uniwersytet Marii Curie-Skłodowskiej w Lubliniel \\ k.nieweglowski.Ibn@gmail.com
}

\title{
Metody tranzytu poczty dyplomatycznej w prawie międzynarodowym publicznym
}

\author{
Methods of transit of diplomatic bag in international law
}

\begin{abstract}
STRESZCZENIE
Prawidłowo funkcjonująca instytucja poczty dyplomatycznej jest elementem niezbędnym do skutecznej działalności misji dyplomatycznych. W Konwencji brak jest definicji poczty dyplomatycznej, jednakże ten problem był wielokrotnie podnoszony przez przedstawicieli doktryny jak i przez Komisję Prawa Międzynarodowego. W porozumiewaniu się z rządem czy innymi podmiotami misja może używać wszelkich odpowiednich środków, w szczególności przy pomocy kuriera dyplomatycznego, również ad hoc czy tzw. poczty kapitańskiej.
\end{abstract}

Słowa kluczowe: dyplomacja; Komisja Prawa Międzynarodowego; Konwencja wiedeńska o stosunkach dyplomatycznych; kurier dyplomatyczny; poczta dyplomatyczna.

\section{WSTĘP}

Dyplomacja towarzyszy cywilizacji ludzkiej od zarania starożytności ${ }^{1}$. Już pierwsze państwa starożytnego świata w celu ochrony swoich interesów dokonywały wszelkich starań, aby korespondencja zawierająca często najbardziej wrażliwe informacje nie dostała się w ręce przeciwników politycznych władcy czy wrogich państw. Jak przytacza P. Barulin, Amenhotep III ze względu na chęć utrzymania korespondencji w tajemnicy kazał ogolić kurierowi głowę a następnie napisać na niej list. W drogę został wyprawiony dopiero po odrośnięciu włosów².

1 J. Sutor, Prawo dyplomatyczne i konsularne, Warszawa 2010, s. 21.

2 P. Barulin, Status diplomaticzieskoj poczty i diplomaticzieskogo kuriera, "Soviet Yearbook of International Law 1983”, Moskwa 1984, s. 121. 
Sprawnie funkcjonująca poczta dyplomatyczna oraz kurierzy dyplomatyczni są warunkiem sine qua non prawidłowego funkcjonowania misji dyplomatycznych, które, aby w pełni wypełniać swoje obowiązki muszą mieć zagwarantowaną możliwość szybkiego i bezpiecznego kontaktu m.in. z własnym rządem. Jako iż światową komunikację w XXI w. zdominował Internet, to sposób ten jest również powszechnie wykorzystywany przez misje dyplomatyczne, ze względu na swoją efektywność, oszczędność czasu oraz oszczędność kosztów³. Niemniej jednak komunikacja za pomocą Internetu wiąże ze sobą szereg zagrożeń. Nie jest bowiem możliwe zagwarantowanie ani stabilności ani bezpieczeństwa transmisji ${ }^{4}$, co w przypadku wymiany najbardziej wrażliwych informacji jest dla komunikujących się sprawą priorytetową. Poczta dyplomatyczna gwarantuje natomiast zarówno nietykalność swojej zawartości jak i pełną autentyczność przesyłanych dokumentów ${ }^{5}$, w związku z czym jest ona ciągle powszechnie używana.

\section{DEFINICJA POCZTY DYPLOMATYCZNEJ}

Mimo znamiennej roli poczty dyplomatycznej oraz kuriera dyplomatycznego dla funkcjonowania misji dyplomatycznych, ich status opierał się na międzynarodowym prawie zwyczajowym oraz kurtuazji aż do chwili uchwalenia Konwencji wiedeńskiej o stosunkach dyplomatycznych ${ }^{6}$.

Konwencja nie definiuje pojęcia „poczta dyplomatyczna” a stwierdza jedynie w art. 27 ust. 1, że przesyłki stanowiące pocztę dyplomatyczną powinny posiadać widoczne znaki zewnętrzne określające ich charakter i mogą zawierać jedynie dokumenty dyplomatyczne lub przedmioty przeznaczone do użytku urzędowego. $\mathrm{W}$ tracie trwania prac nad konwencją wielokrotnie poruszano problematykę definicji tego pojęcia. Zaproponowane przez K. Yokote zamieszczenie wyjaśnienia terminu „poczta dyplomatyczna” miało być gwarantem zachowania przywileju nietykalności poczty dyplomatycznej przy jednoczesnym zapobieganiu jego nadużywania przez państwa wysyłające ${ }^{7}$. G. Amado przyznał, że do nadużyć poczty dyplomatycznej dochodzi niemal codziennie. Stwierdził ponadto, że skoro nie jest możliwe zdefiniowanie tychże nadużyć, to Komisja może zdefiniować samą

3 M. Murphy, The impact of the Internet on diplomatic reporting: how diplomacy training needs to be adjusted to keep peace, Budapeszt 2013, s. 71.

4 United Nations Correspondence Manual. A guide to the drafting, processing and dispatch of official United Nations communications (ST/DCS/4/Rev.1), Nowy Jork 2000, s. 23.

5 T. Kamiński, Status poczty dyplomatycznej studium prawnomiędzynarodowe, Warszawa 2003, s. 11.

6 Konwencja wiedeńska o stosunkach dyplomatycznych, sporządzona w Wiedniu dnia 18 kwietnia 1961 r. (Dz.U.1965.37.232).

Zob. Yearbook of The International Law Commission 1957 Volume I s. 79 - 80. 
pocztę dyplomatyczną i stwierdzić, że jako „środek dostarczania korespondencji dyplomatycznej pomiędzy państwami a ich misjami jest ona nietykalna”. próby zdefiniowania terminu „poczta dyplomatyczna” poprzez jej nietykalność nie znalazła szerokiego poparcia, gdyż jak uważano lepiej oprzeć definicję na określeniu jak poczta ma wyglądać i co zawierać, a zagadnienie nietykalności pozostawić odrębnym przepisom. Pojawiły się więc kolejne sugestie zdefiniowania poczty dyplomatycznej poprzez określenie jej zawartości. Taką propozycją była propozycja L. Padilla Nervo, wedle której ,poczta dyplomatyczna powinna być wykorzystywana jedynie dla przekazywania korespondencji dyplomatycznej”" stanowisko to różniło się od propozycji J. Spiropoulos'a, który proponował, aby obok korespondencji dyplomatycznej w poczcie dyplomatycznej mogły znaleźć się jednak również inne dokumenty ${ }^{10}$. Stanowisko pośrednie w tej materii wyrażone zostało przez M. Bartos'a, który stwierdził, że „poczta powinna zawierać tylko korespondencję i wydruki dla celów misji, chociaż w wyjątkowych sytuacjach mogłaby zawierać inne przedmioty przekazywane w celach dowodowych"11.

Najważniejszą definicją sformułowaną przez doktrynę, a dokładniej przez wspomnianego już P. Barulina jest podwójna definicja poczty dyplomatycznej wyróżniająca jej wąskie oraz szerokie znaczenie. Poczta dyplomatyczna sensu largo to ,jeden ze sposobów komunikowania się pomiędzy państwem (występującym z reguły poprzez MSZ) a misjami dyplomatycznymi, konsularnymi i innymi, stosowanymi w celu zapewnienia normalnego funkcjonowania tych ostatnich zgodnie z regułami prawa międzynarodowego" 12 . Jest to definicja niezwykle uniwersalna ze względu na wymieniony krąg podmiotów oraz ponadczasowa poprzez powołanie się na zgodność z prawem międzynarodowym, które jest zmienne w czasie ${ }^{13}$. Tak zdefiniowana poczta dyplomatyczna pozostawia szerokie pole do interpretacji, dlatego Barulin zaproponował również definicję sensu stricto, poprzez określenie poczty dyplomatycznej jako zamkniętą przesyłki opatrzonej woskowymi lub ołowianymi pieczęciami przez właściwe organy państwa, która posiada widoczne oznaczenia zewnętrzne oraz dołączony dokument wskazujący na jej charakter, zawiera urzędową korespondencję, dokumenty lub przedmioty przeznaczone do urzędowego użytku, jest wysyłana przez państwo do jego przedstawicielstw za granicą lub przez przedstawicielstwa do państwa, bądź też pomiędzy sobą niezależnie od miejsca położenia misji, jest przesyłana za pomocą kuriera dyplomatycznego, kapitana lub członka załogi morskiego lub powietrznego statku, jak i bez eskorty

\footnotetext{
Ibidem, s. 79, nb. 11.

Ibidem, s. 81, nb. 32.

Ibidem, s. 79, nb 9.

Ibidem, s. 78, nb 90.

2 P. Barulin, op. cit. s. 159.

13 T. Kamiński, op. cit. s. 64.
} 
kuriera za pomocą zwykłych kanałów pocztowych oraz jest poddana specjalnemu reżimowi na podstawie umownego i zwyczajowego prawa międzynarodowego jak również na podstawie praktyki państw ${ }^{14}$.

Jak wspomniano, w Konwencji wiedeńskiej o stosunkach dyplomatycznych brak jest definicji poczty dyplomatycznej. Jednakże w komentarzu do ostatecznej wersji projektowanych artykułów tej konwencji można znaleźć stwierdzenie, że poczta dyplomatyczna „może być określana jako torba, worek, koperta lub jakikolwiek pakunek zawierający dokumenty i (lub) przedmioty przeznaczone do użytku urzędowego. Zgodnie ze zmienioną treścią tego paragrafu poczta musi posiadać widoczne znaki zewnętrzne określające jej charakter"15. Warto w tym miejscu wspomnieć, iż zgodnie $\mathrm{z}$ art. 32 Konwencji wiedeńskiej o prawie traktatów ${ }^{16}$ dozwolone jest w procesie interpretacji traktatu odwoływanie się do uzupełniających środków interpretacji łącznie z pracami przygotowawczymi do traktatu oraz okolicznościami jego zawarcia, aby potwierdzić wynik wykładni przeprowadzonej w oparciu o tzw. ogólną regułę interpretacyjną o której mowa w art. 31 lub dla ustalenia znaczenia, gdy interpretacja oparta na art. 31 pozostawia znaczenie dwuznacznym lub niejasnym albo prowadzi do rezultatu absurdalnego lub nierozsądnego. Należy jednak pamiętać o art. 4 Konwencji wiedeńskiej o prawie traktatów zgodnie z którym „konwencję stosuje się jedynie do traktatów zawartych przez państwa po wejściu niniejszej konwencji w życie w odniesieniu do tych państw".

W związku z powyższym, aby powstała możliwość korzystania z prac przygotowawczych w procesie interpretacji Konwencji wiedeńskiej o stosunkach dyplomatycznych należy wykazać, iż powoływanie się na prace przygotowawcze przy interpretowaniu umowy międzynarodowej funkcjonowało w okresie poprzedzającym wejście w życie Konwencji wiedeńskiej o prawie traktatów. S. E. Nahlik stwierdził, że w doktrynie istniały trzy koncepcje interpretacji traktatów - intencjonalna, obiektywistyczna oraz funkcjonalna. Koncepcja intencjonalna „stara się wyśledzić rzeczywistą intencję stron w chwili zawierania traktatu. Docieka jej wszelkimi sposobami, sięgając obficie do materiałów przygotowawczych oraz okoliczności, jakie towarzyszyły powstaniu umowy"17. Reguła ta, w świetle poglądów doktryny, zdaje się wywodzić od Grocjusza, który dopuszczał usuwanie niejasności w interpretacji poprzez powiązanie ze źródłem. „Ma ono miejsce wówczas, gdy te same słowa, choćby wypowiedziane w innym miejscu i przy innej sposobności, pochodzą z tej samej woli, skąd rodzi się domniemanie, ponieważ w razie wątpli-

14 Ibidem, s. 65.

15 Yearbook of The International Law Commission 1958 Volume II, s. 97.

16 Konwencja Wiedeńska o Prawie Traktatów sporządzona w Wiedniu dnia 23 maja 1969 r.

(Dz.U. $1990 \mathrm{nr} 74$ poz. 439)

17 S. E. Nahlik, Kodeks Prawa Traktatów, Warszawa 1976. 
wości uważa się, że wola zainteresowanych była ze sobą zgodna"18. Jak twierdzi Tomasz Kamiński, zgodnie z powyższym „można przyjąć fikcję tożsamości KPM ONZ, jako twórcy projektu, z wolą państw - stron tej konwencji[...]" ${ }^{19}$ oraz „za dopuszczalne należy uznać posługiwanie się definicją zawartą w komentarzu Komisji jako oficjalną definicją poczty dyplomatycznej, sformułowaną na gruncie Konwencji wiedeńskiej z 1961 roku"20.

\section{PRZEKAZYWANIE I PRZEWÓZ POCZTY DYPLOMATYCZNEJ}

Art. 27 Konwencji wiedeńskiej o stosunkach dyplomatycznych wskazuje bezpośrednio na trzy główne sposoby przekazywania poczty dyplomatycznej. Ust. 5 reguluje status kuriera dyplomatycznego stanowiąc, że „kurier dyplomatyczny, który powinien być zaopatrzony w urzędowy dokument określający jego charakter i liczbę przesyłek stanowiących pocztę dyplomatyczną, będzie chroniony przez państwo przyjmujące w czasie pełnienia swych funkcji. Korzysta on z nietykalności osobistej oraz nie podlega aresztowaniu lub zatrzymaniu w żadnej formie", ust. 6 dotyczy kuriera $a d$ hoc - „Państwo wysyłające lub misja mogą wyznaczać kurierów dyplomatycznych ad hoc. W takich wypadkach postanowienia ustępu 5 niniejszego artykułu będą miały również zastosowanie, z tym jednak że wymienione tam immunitety przestaną być stosowane z chwilą, gdy kurier taki doręczy odbiorcy powierzoną sobie pocztę dyplomatyczną.", a ust. 7 traktuje o tzw. poczcie kapitańskiej stanowiąc, iż „Poczta dyplomatyczna może być powierzona kapitanowi powietrznego statku handlowego, który ma lądować w dozwolonym porcie wejściowym. Powinien on być zaopatrzony w urzędowy dokument określający liczbę przesyłek stanowiących pocztę, lecz nie będzie on jednak uważany za kuriera dyplomatycznego. Misja może wysłać jednego ze swych członków w celu bezpośredniego i swobodnego odbioru poczty dyplomatycznej od kapitana statku powietrznego.". Wyliczenie to nie jest jednak wyczerpujące ${ }^{21}$, gdyż z treści ust. 1 dotyczącego swobody porozumiewania się misji dla wszelkich celów urzędowych wynika, iż „w porozumiewaniu się z rządem oraz z innymi misjami i konsulatami państwa wysyłającego, bez względu na miejsce ich siedziby, misja może używać wszelkich odpowiednich środków, łącznie z kurierami dyplomatycznymi oraz korespondencją sporządzoną kodem lub szyfrem." Przepis ten stanowi więc podstawę

${ }_{18}$ H. Grotius, O prawie wojny i pokoju. Trzy księgi, w których znajdują wyjaśnienie prawo natury i prawo narodów, a także główne zasady prawa publicznego, Warszawa 1957, t. I, s. 546.

19 T. Kamiński, op. cit., s. 71.

20 Ibidem.

21 Ibidem, s. 119. 
dla korzystania przez misje dyplomatyczne ze wszystkich uznanych przez nie za właściwe środków przekazywania poczty dyplomatycznej ${ }^{22}$.

\section{KURIERZY DYPLOMATYCZNI}

Początki kształtowania się instytucji kuriera dyplomatycznego sięgają zarania dyplomacji. Pierwsza zorganizowana służba kurierska została utworzona około 2.500 roku p.n.e. ${ }^{23}$. Do wejścia w życie Konwencji wiedeńskiej o stosunkach dyplomatycznych status kurierów dyplomatycznych regulowany był przez międzynarodowe prawo zwyczajowe. Za przykładowe definicje kuriera dyplomatycznego sformułowane przez doktrynę można przytoczyć definicję H. P. Kaula - „Kurier to wysłannik należycie upoważniony przez państwo wysyłające, który bądź w charakterze stałego zawodu, bądź też powoływany tylko w specjalnych okazjach jako kurier ad hoc, obejmuje pieczę nad pocztą dyplomatyczną dla jej transportu i dostarczania do punktu docelowego" ${ }^{24}$ czy definicję W. H. Bruce'a, zgodnie z którą „Kurier dyplomatyczny jest wysłannikiem rządowym, którego misja polega wyłącznie na wypełnianiu szybko i bezpiecznie, potrzeb komunikacyjnych jego (jej) rządu"25.

Już w początkowych fazach prac przygotowawczych KPM ONZ nad postanowieniami dotyczącymi tego zagadnienia widoczny był podział przytoczonego wyżej ust. 5 konwencji na dwie części. Pierwsza dotyczy dokumentów dowodzących jego statutu, a druga zakresu przysługującej mu ochrony. Kurier dyplomatyczny powinien być zaopatrzony w paszport, z reguły paszport dyplomatyczny wyposażony w odpowiednie wizy zgodnie z trasą przejazdu oraz tzw. list kurierski, czyli dokument zaświadczający o podróżowaniu w charakterze kuriera dyplomatycznego oraz określający liczbę przesyłek stanowiących pocztę dyplomatyczną ${ }^{26}$. Dokument ten występuje zazwyczaj w postaci blankietu opatrzonego pieczęciami resortu spraw zagranicznych lub danej misji dyplomatycznej i podpisanego przez upoważnionego przedstawiciela resortu spraw zagranicznych lub misji państwa wysyłającego ${ }^{27}$. Kurier dyplomatyczny ma być w świetle art. 27 ust. 5 Konwencji wiedeńskiej o stosunkach dyplomatycznych chroniony przez państwo przyjmujące w czasie pełnienia swoich funkcji. Początkowo, w świetle projektu postanowień dotyczących kuriera dyplomatycznego, nietykalność miała kurierowi przysługiwać

22 Ibidem.

23 W. H. Bruce, Secret Messengers, How Governments Correspond, College Park 1995, s. 27 - 28.

24 H. P. Kaul, Couriers [w:] R. Bernhardt (red.), Encyclopedia of Public International Law, Ninth instalment- International Relations and Legal Cooperation in General. Diplomacy and Consular Relations, Amsterdam - Nowy Jork - Oxford - Tokio, 1986, s. 49.

25 W. H. Bruce, op. cit., s. 17.

26 J. Sutor, op. cit., s. 302.

27 T. Kamiński, op. cit., s. 128. 
tylko „podczas podróży” w charakterze kuriera dyplomatycznego ${ }^{28}$. Zapis ten spotkał się z krytyką m.in. ze strony G. Fitzmaurice'a, który stwierdził, że przyjmując takie ograniczenie nietykalności kurier byłby pozbawiony przywileju nietykalności w przerwie pomiędzy przyjazdem i dostarczeniem poczty a odjazdem i zabraniem poczty. Według Fitzmaurice'a kurier nie może zostać w takiej sytuacji pozbawiony przywileju nietykalności, chyba żeby wyjechał w tym czasie na urlop ${ }^{29}$. Ta uwaga została poparta przez G. I. Tunkina, który stwierdził, iż sformułowanie „podczas podróży" może być przedmiotem nadmiernie restrykcyjnej interpretacji ${ }^{30}$. W rezultacie, Francja zaproponowała sformułowanie, że kurier jest chroniony „w czasie pełnienia swych funkcji”, które następnie znalazło się w treści przyjętej przez Państwa. Zakres ochrony przysługującej kurierowi dyplomatycznemu nie jest jednak w konwencji sprecyzowany. Stanowi ona jedynie, iż korzysta on z nietykalności osobistej oraz nie podlega aresztowaniu lub zatrzymaniu w żadnej formie. Mimo zapoczątkowania w 1979 r. prac KPM mającej na celu kodyfikacje zasad i norm dotyczących statusu poczty i kuriera dyplomatycznego ${ }^{31}$ nie udało się przyjąć norm dotyczących zakresu przywilejów i immunitetów kurierów dyplomatycznych. Kwestia ta jest obecnie regulowana kurtuazją międzynarodową.

\section{KURIERZY DYPLOMATYCZNI AD HOC}

Zgodnie z treścią art. 27 ust. 6 Konwencji wiedeńskiej o stosunkach dyplomatycznych statut kuriera ad hoc jest zrównany ze kuriera zawodowego. Przysługuje im taki sam zakres ochrony pod warunkiem posiadania dokumentów identyfikujących go oraz określających liczbę i rodzaj przesyłek stanowiących pocztę dyplomatyczną, czyli tzw. listu kurierskiego. Pomiędzy kurierami ad hoc oraz kurierami zawodowymi można jednakże wskazać dwie zasadnicze różnice ${ }^{32}$. Pierwsza dotyczy zdolności desygnowania kurierów ad hoc. Kurierzy zawodowi są powiązani stale z państwem wysyłającym i są przyjmowani do służby przez kompetentny organ resortu spraw zagranicznych państwa wysyłającego uzyskując jednocześnie status pracownika tego urzędu. Kurierzy ad hoc natomiast mogą być wyznaczani zarówno przez państwo wysyłające jak i przez daną misję dyplomatyczną. Nie musi być on pracownikiem urzędu resortu spraw zagranicznych czy dyplomatą - może zostać powołany bezpośrednio przez misję dyplomatyczną, której zależy na nawiązaniu

${ }_{28}$ Yearbook of The International Law Commission Volume II Part II, s. 139, nb. 66.

29 Ibidem, s. 140, nb. 2.

30 Ibidem, s. 140, nb, 7.

31 Zob. Consideration of the draft articles on the status of the diplomatic courier and the diplomatic bag not accompanied by diplomatic courier and of the draft optional protocols therto - Report of the Sith Committee, A/50/644.

32 T. Kamiński, op. cit., s. 135. 
pilnego kontaktu z państwem wysyłającym. Drugim elementem bardziej widocznym w treści ust. 6 jest czas trwania przysługujących kurierowi immunitetów. Przewidziana w ust. 5 nietykalność osobista, zakaz aresztowania lub zatrzymania w żadnej formie wygasa bowiem w przypadków kurierów ad hoc z chwilą, gdy kurier taki doręczy odbiorcy powierzoną sobie pocztę dyplomatyczną. Niemniej jednak, ze względu na powszechną praktykę powierzania funkcji kuriera ad hoc osobom i tak już wyposażonym $\mathrm{w}$ immunitetu $\mathrm{z}$ innego tytułu niż z racji pełnienia funkcji kuriera $a d$ hoc „,wygaśnięcie immunitetów kurierskich z chwilą dostarczenia przewożonej przez nich poczty nie będzie aż tak istotne" ${ }^{33}$.

\section{POCZTA KAPITAŃSKA ORAZ INNE SPOSOBY PRZEKAZYWANIA POCZTY DYPLOMATYCZNEJ}

Trzecim sposobem tranzytu poczty dyplomatycznej wspomnianym bezpośrednio w Konwencji wiedeńskiej o stosunkach dyplomatycznych jest przewóz poczty poprzez powierzenie jej kapitanowi powietrznego statku handlowego, który ma lądować w dozwolonym porcie wejściowym. Musi być on zaopatrzony w urzędowy dokument określający liczbę przesyłek (odpowiednik tzw. listu kurierskiego). Ponadto z treści art. 27 ust. 7 wynika, iż misja może wysłać jednego ze swych członków w celu bezpośredniego i swobodnego odbioru poczty dyplomatycznej od kapitana statku powietrznego. Państwo przyjmujące ma więc obowiązek powstrzymania się od jakichkolwiek czynności przeszkadzających takiemu odbiorowi. Znamiennym jest również fakt, iż kapitan powietrznego statku handlowego wyposażony w tzw. list kurierski nie jest uważany za kuriera dyplomatycznego, a więc nie przysługują mu immunitety i przywileje przewidziane dla kurierów zawodowych i kurierów ad hoc. W trakcie prac KPM można znaleźć poglądy, iż „niezaprzeczalnym jest fakt, że poczta dyplomatyczna udziela nietykalności osobie ją przewożącej” i dlatego kapitan powietrznego statku handlowego staje się nietykalny z chwilą otrzymania poczty dyplomatycznej i właściwych dokumentów, a jego nietykalność wygasa $\mathrm{z}$ chwilą doręczenia poczty ${ }^{34}$. Wydaje się jednak, że skoro konwencja expressis verbis stanowi, iż kapitan powietrznego statku handlowego nie jest uważany za kuriera dyplomatycznego to pogląd taki stanowi wykładnie contra legem. Warto wspomnieć również, iż w Konwencji wiedeńskiej z 1963 r. o stosunkach konsularnych $^{35} \mathrm{~W}$ art. 35 ust. 7 przewiduje możliwość przewozu poczty konsularnej również przez kapitana statku morskiego.

33 Ibidem, s. 136.

34 Yearbook of The International Law Commission 1957 Volume I Part II, s. 142, nb. 27.

35 Konwencja wiedeńska o stosunkach konsularnych sporządzona w Wiedniu dnia 24 kwietnia 1963 r. (Dz.U.82.13.98). 
Poczta dyplomatyczna może również być przewożona przy wykorzystaniu zwykłych kanałów pocztowych. Taki tranzyt jest na tyle powszechny w praktyce państw, że w trakcie prac KPM, podczas X sesji R. J. Alfaro uznał projektowany artykuł za niekompletny, gdyż w świetle jego treści poczta dyplomatyczna przewożona za pomocą poczty publicznej nie korzystałaby z nietykalności. Zaproponował on poprawkę, która znalazła się w finalnej wersji art. 27 ust. 2 konwencji stanowiącą, iż „korespondencja urzędowa misji jest nietykalna”.

Kwestia tranzytu poczty dyplomatycznej pocztą publiczna był również poruszany w ramach Światowego Związku Pocztowego (ang. Universal Postal Union - UPU), gdyż na kongresie w Lozannie w 1974 r. UPU postanowił kontynuować badania nad „oficjalną korespondencją misji dyplomatycznych, konsulatów oraz międzynarodowych organizacji rządowych"36. Wyniki tych badań zostały zaprezentowane w 1979 r. na kongresie w Rio de Janeiro ${ }^{37}$. Uregulowania w tym zakresie uznano za wystarczające oraz nie zgodzono się na wprowadzenie przepisów dotyczących tego zagadnienia do dokumentów organizacji jednocześnie akceptując korzystanie z międzynarodowych usług pocztowych dla przesyłania poczty dyplomatycznej w oparciu o bilateralne oraz multilateralne umowy międzynarodowe ${ }^{38}$.

Jak już wspomniano, art. 27 ust. 1 stanowi podstawę dla korzystania przez misje dyplomatyczne ze wszystkich uznanych przez nie za właściwe środków przekazywania poczty dyplomatycznej. W dokumentacji KPM jako przykłady przewozu za pomocą „wszelkich odpowiednich środków” wymienione zostały transport kolejowy, transport samochodami ciężarowymi, frachtem lotniczym oraz drogą morską ${ }^{39}$. Przesyłka musi być wówczas wyposażona w odpowiedni dokument wskazujący na jej status.

\section{ZAKOŃCZENIE}

Mimo niezwykle istotnego znaczenia dla pracy misji dyplomatycznej, zagadnienie tranzytu poczty dyplomatycznej nadal w znacznej mierze opiera się na zwyczaju i kurtuazji międzynarodowej. Mimo ukończenia w 1989 r. przez KPM prac nad kodyfikacją statusu łącznie z przywilejami i immunitetami kuriera i poczty dyplomatycznej, w tym przewożonej bez kuriera dyplomatycznego oraz zaleceniem ZO ONZ zwołanie konferencji pełnomocników ${ }^{40}$, to sprawa ta nie spotkała

\footnotetext{
36 Yearbook of The International Law Commission 1983 Volume II Part I, s. 120, nb. 313.

37 Ibidem, s. 121, nb. 316.

38 Ibidem, s. 121, nb. 317.

39 Ibidem, s. 121, nb. 320.

$40 \mathrm{~A} / 44 / 10$, Report of the International Law Commission on the work of its forty-first session, 2 May - 21 July 1989, Official Records of the General Assembly, Forty-fourth session, Supplement No. 10 , s. 13 , nb. $66-68$.
} 
się z należytym odzewem ze strony państw. W 1995 r. Zgromadzenie Ogólne ONZ przeprowadziło konsultacje przesyłając projekt przeszłej konwencji do wiadomości państw członkowskich ONZ, jednakże mimo upływu ponad dwóch dekad sprawa nie pojawiła się na porządku dnia Zgromadzenia Ogólnego $\mathrm{ONZ}^{41}$. Zdaniem autora rozwój technologiczny, a co za tym idzie powszechne korzystanie z sieci Internet do przesyłu dokumentów przez misje dyplomatyczne lub państwa wymusza na społeczności międzynarodowej podjęcie kroków zmierzających do rozważenia na nowo przepisów dotyczących przewozu poczty dyplomatycznej. Mimo, iż w literaturze pojawiają się zdania, iż przepisy Konwencji wiedeńskiej o stosunkach dyplomatycznych można zastosować do korespondencji przy wykorzystaniu sie$\mathrm{ci}^{42}$ to nowe, świeże spojrzenie na zagadnienie statusu poczty dyplomatycznej, jej przewozu i przywilejów niewątpliwie przyczyni się do rozwiania wątpliwości co do prawnych uregulowań nowoczesnych sposobów komunikacji.

\section{BIBLIOGRAFIA}

Barulin P., Status diplomaticzieskoj poczty i diplomaticzieskogo kuriera, "Soviet Yearbook of International Law 1983", Moskwa 1984,

Bruce W. H., Secret Messengers, How Governments Correspond, College Park 1995,

Choi W., Diplomatic and Consular Law in the Internet Age [w:] Singapore Year Book of International Law, Singapur 2006,

Consideration of the draft articles on the status of the diplomatic courier and the diplomatic bag not accompanied by diplomatic courier and of the draft optional protocols therto-Report of the Sith Committee, A/50/644,

Grotius H., O prawie wojny i pokoju. Trzy księgi, w których znajduja wyjaśnienie prawo natury i prawo narodów, a także główne zasady prawa publicznego, Warszawa 1957,

Kamiński T., Status poczty dyplomatycznej studium prawnomiędzynarodowe, Warszawa 2003,

Kaul H. P., Couriers [w:] Bernhardt R. (red.), Encyclopedia of Public International Law, Ninth instalment- International Relations and Legal Cooperation in General. Diplomacy and Consular Relations, Amsterdam - Nowy Jork - Oxford - Tokio, 1986,

Konwencja Wiedeńska o Prawie Traktatów sporządzona w Wiedniu dnia 23 maja 1969 r. (Dz.U. $1990 \mathrm{nr} 74$ poz. 439),

Konwencja wiedeńska o stosunkach dyplomatycznych, sporządzona w Wiedniu dnia 18 kwietnia 1961 r. (Dz.U.1965.37.232),

Konwencja wiedeńska o stosunkach konsularnych sporządzona w Wiedniu dnia 24 kwietnia 1963 r. (Dz.U.82.13.98),

Murphy M., The impact of the Internet on diplomatic reporting: how diplomacy training needs to be adjusted to keep peace, Budapeszt 2013,

Nahlik S. E., Kodeks Prawa Traktatów, Warszawa 1976,

${ }^{41}$ J. Sutor, op. cit., s. 302.

42 Zob. W. Choi, Diplomatic and Consular Law in the Internet Age [w:] Singapore Year Book of International Law, Singapur 2006.; P. Sullaj, Digitalization of diplomacy: A new way of making diplomacy? https://www.unikore.it/index.php/numero-6/sullay (dostęp: 03.11.2018 r.). 
Report of the International Law Commission on the work of its forty-first session, 2 May - 21 July 1989,

Official Records of the General Assembly, Forty-fourth session, Supplement No. 10. (A/44/10),

Sullaj P., Digitalization of diplomacy: A new way of making diplomacy? https://www.unikore.it/index. php/numero-6/sullay (dostęp: 03.11.2018 r.),

Sutor J., Prawo dyplomatyczne i konsularne, Warszawa 2010,

United Nations Correspondence Manual. A guide to the drafting, processing and dispatch of official United Nations communications, Nowy Jork 2000, (ST/DCS/4/Rev.1),

Yearbook of The International Law Commission 1957 Volume I Part I,

Yearbook of The International Law Commission 1957 Volume I Part II,

Yearbook of The International Law Commission 1958 Volume II Part I,

Yearbook of The International Law Commission 1983 Volume II Part I.

\section{SUMMARY}

A properly functioning institution of diplomatic bag is the sine qua non of effective operation of diplomatic missions. There is no legal definition of diplomatic bag in international law however, this problem was repeatedly raised by representatives of the doctrine and by the International Law Commission. In communicating with the Government and the other missions and consulates of the sending State the mission may employ all appropriate means, including diplomatic couriers also as courier ad hoc or so - called captain's mail.

Keywords: diplomacy, diplomatic bag, diplomatic courier, International Law Commission, Vienna Convention on Diplomatic Relations. 